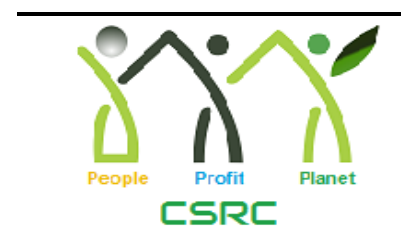

Volume and Issues Obtainable at Center for Sustainability Research and Consultancy

Journal of Business and Social Review in Emerging Economies

ISSN: 2519-089X (E): 2519-0326

Volume 6: Issue 1 June 2020

Journal homepage: www.publishing.globalcsrc.org/jbsee

\title{
The Governance of Corporate Sustainability in the Middle East: Preliminary Insights
}

\author{
${ }^{1}$ Zeeshan Mahmood, ${ }^{2}$ Maha Faisal Alsayegh
}

${ }^{1}$ Department of Commerce, Bahauddin Zakariya University zeeshanmahmood@bzu.edu.pk ${ }^{2}$ Department of Accounting, Faculty of Economics and Administration, King Abdulaziz University, Jeddah 21589, Saudi Arabia; mfalsayegh@kau.edu.sa

\begin{tabular}{l}
\hline ARTICLE DETAILS \\
\hline History \\
Revised format: May 2020 \\
Available Online: June 2020 \\
\\
\hline Keywords \\
Sustainability Governance, \\
Corporate Governance, \\
Corporate Sustainability, \\
S\&P/Hawkamah, \\
Pan Arab ESG Index, \\
Content Analysis, \\
Middle East
\end{tabular}

JEL Classification

M20, M40

\begin{abstract}
This paper explores the extent to which companies incorporate best practices for the governance of sustainability in the Middle East. The empirical content in this paper is based on the analysis of disclosures in the annual and sustainability reports of fifteen companies from the Middle East that are listed in the S\&P/Hawkamah Pan Arab ESG Index. The research presented in this paper shed the light on some of the practices currently being employed in Middle Eastern companies to govern and manage their sustainability strategies. This study found that top Middle Eastern companies are catching up the global best practices in incorporating sustainability into some structures and processes. However, sustainability governance structures and processes where middle eastern companies are lagging include sustainability committee at board-level, sustainability related mission, vision and values, sustainability assurance, sustainability related trainings and separate sustainability department. In addition, this paper provides several illustrations of how top middle eastern companies are exhibiting sustainability governance structures and processes in their sustainability reports. These findings will be useful in understanding the current practices of sustainability governance in the middle east and can inform the policy makers for the possibility of regulation in this area. This research is equally beneficial for companies and managers in benchmarking their practices against sustainability leaders and to learn how to embed sustainability into their business practices.
\end{abstract}

(C) 2020 Center for Sustainability Research and Consultancy Pakistan under a Creative Commons Attribution-NonCommercial-ShareAlike 4.0

Corresponding author's email address: zeeshanmahmood@bzu.edu.pk

Recommended citation: Mahmood, Z. and Alsayegh, M.F. (2020). The Governance of Corporate Sustainability in the Middle East: Preliminary Insights. Journal of Business and Social Review in Emerging Economies, 6 (2), 715-731

\section{Introduction}

Many countries and organisations around the world are intrigued by the concept of sustainable development. Governmental and non-governmental organisations are making efforts for the initiation and institutionalization of sustainable development (Unerman, Bebbington, \& O'Dwyer, 2010). For instance, the Government of UAE, both at a federal and Emirate level, intends to become "sustainable" and has included "sustainable development" one of the key goals of UAE Vision 2021 (Academy, 2017). In this context, sustainability related regulation and policies are increasing. For instance, Estidma ('sustainability' in Arabic) is the first indigenous sustainability framework in the Middle East that is intended to promote sustainable development through its green building rating system (Issa \& Al Abbar, 2015). In addition to the regulatory frameworks, there is an evidence of increased sustainable investments around the globe 
(Chartered, 2018). According to the Asia Sustainable Investing Review (2018) sustainable investments is expected to grow from $20 \%$ to $23 \%$ (of the total investment portfolio of active investors) in the next 3 years. The level of sustainable investments in the Middle East is low but growing steadily (IFC, 2010). Following investor demands and to track the performance of companies that shows excellence in the areas of environmental, social and governance (ESG) matters, Standard \& Poor's and Hawkamah (the Institute for Corporate Governance for the MENA region) have jointly created the S\&P/Hawkamah ESG Index ${ }^{1}$. This is the first ESG Index in the MENA region which aims to raise the profile of companies adopting 'sustainable business practices' and reporting. The index provides comparable qualitative information on companies that operate in different MENA countries including Saudi Arabia, the United Arab Emirates, Kuwait, Qatar, Bahrain, Oman, Jordan, Egypt, Lebanon, Morocco and Tunisia (Vinke \& El-Khatib, 2012). Because of institutionalization of sustainability at various levels and increasing awareness and concerns by investors, companies and their managers are under pressure to address the issue of sustainability (Gray, Adams, \& Owen, 2014).

From a corporate perspective, sustainability refers to the global responsibility of corporations towards economic, social, and environmental impacts. Corporate sustainability, that balanced the interests of all stakeholders including that of shareholders, will ensure sustainable value creation for the long-term success of the company. Sustainability issues poses substantial opportunities as well as threats that can affect the performance of a company (Doppelt, 2017). For corporations to act responsibly and be profitable, there is a need of governance structure that should integrate sustainability issues in the decision-making (Spitzeck, 2009). Various mechanisms for overseeing sustainability risks are required to capitalize the opportunities and avoid threats. The Governance of sustainability requires changes to board composition and expertise in effect can enhance company strategy and vision. Effective sustainability governance ensures that opportunities and threats related to sustainability are well managed. In today's world, governance of sustainability can provide competitive advantage and a long-term success factor for any firm (Porter \& Van der Linde, 1995). Governance of sustainability requires the due consideration of economic, social and environmental affairs in the board's decision making in an integrated way. Sustainability governance is concerned with the potential sustainability performance of the company in the future and shall be considered as enablers of potential performance (Schneider \& Meins, 2012).

Plethora of research exists on the adoption of sustainability initiatives. Existing literature explains various societal, institutional, organizational and individual drivers for sustainability adoption. Very few studies focused on the implementation and institutionalization of sustainability within the company (Asif, Searcy, Zutshi, \& Ahmad, 2011). Empirical investigations in the area of sustainability governance still remains to be explored (Klettner, Clarke, \& Boersma, 2014). However, the governance of sustainability is an emerging area of research (Aras \& Crowther, 2008). Very recently, few researchers started exploring sustainability governance practices and their impacts on sustainability assurance, sustainability reporting and sustainability performance. This paper contributes to the recent research agenda by taking an account of sustainability governance practices in the Middle Eastern companies. Majority of big companies in the middle east are currently involved in some form of sustainability performance and reporting. Recently, a survey that conducted by KPMG (2017) showed that there is an increasing number in sustainability reports level amongst the top 100 UAE listed companies. About 44 of the top 100 companies in the UAE produced these reports in 2017 co mpared to 36 in 2016; which represent an increase of $22 \%$ in sustainability reporting rates in the country. This increasing level in the sustainability reporting amongst the top 100 UAE companies can be attributed to the sustainable development agenda that was initiated and adopted by the government and their noticeable efforts to position the country as one of the global leaders in the sustainability. It does also reflect a growing level of awareness amongst the top 100 UAE companies on sustainable development practices.

This paper explores how and to what extent these companies have adopted the best practices for the governance of sustainability in the Middle East. Doing so, this paper explores the interface between corporate governance and corporate sustainability. This research will inform managers, regulators and policy-makers about existing sustainability

${ }^{1}$ https://www.hawkamah.org/uploads/Factsheet_SP_Hawkamah_ESG_Pan_Arab_Index_A4.pdf 
governance practices which can be the basis for improvements in governance practices, regulation and policy making.

\section{Literature Review}

Governance very broadly means a "process of supervision and control intended to esnsure that an entity's management acts in accordance with the interests of its constituents" (Gray, et al., 2014, p.258). According to Cadbury (2000, p.8) corporate governance is "the system by which companies are directed and controlled". Corporate governance involves board structures as well as reporting lines and formal organization within the firm (Spitzeck \& Hansen, 2010). Corporate governance also constitutes "the sum of all formal procedures according to which a firm's decisions are made" (De Graaf \& Stoelhorst, 2013, p.286). Corporate Governance is generally considered as a mechanism to protect shareholder wealth. However, these days the scope of corporate governance is extended to protect society and environment (Gray, et al., 2014). The extended scope is because of increasing demand from stakeholders to be socially and environmentally responsible. Companies are now devising social and environmental policies, implementing sustainability management systems, and putting structures in place to monitor sustainability issues at board level. Sustainability is now becoming part of the strategic management process of companies. Focus on sustainability shift the priorities at different levels (shareholder, board, managerial) from short-term to long-term. This long-term focus enhances the role of corporate governance in monitoring corporate sustainability. In this context, governance of sustainability (sustainability governance) can be understood as part of overall system of corporate governance that is mainly concerned with sustainability issues. Such governance structures mediate the impact of social and environmental pressures and can foster sustainability (Aras \& Crowther, 2008).

Sustainability governance can also be understood as part of organizational structures and processes needed to implement corporate sustainability (Asif, Searcy, Zutshi, \& Fisscher, 2013). For sustainability to be truly integrated and embedded within organisations, there is a need of a clear direction, strategic influence and committed leadership - which constitutes the sustainability governance structure (Benn, Edwards, \& Williams, 2014). According to Schneider \& Meins (2012) there are three dimensions of sustainability governance. First dimension includes the strategic and structural features of sustainability governance that set the overall direction of a firm with respect to sustainability. Social and environmental impacts in addition to economic impacts becomes an important concern in the strategic decision making (Benn, et al., 2014). At this level, best practices in sustainability governance include mission, vision and strategy related to sustainability, dedicated head of sustainability, formal board committees dealing with sustainability issues $^{2}$. Second dimension is related to the processes within organisations for the implementation and control of corporate sustainability. To implement sustainability strategies determined at the first level, there is a need for the implementation within organizational processes. At this procedural level, governance elements include: environmental management system, ISO standards, UNGC signatory, Sustainability reporting and assurance, CSR orientation and trainings, leadership, cross-functional executive sustainability committee, sustainability teams, working groups and external advisory councils (Boiral, 2007). Third dimension is related to the features concerning the design of exterior relations with firms' environment.

Realizing the importance of sustainability governance structures as enablers of sustainable value creation, firms are now taking initiatives to institutionalize sustainability structures within organisations (Klettner, et al., 2014; Lock \& Seele, 2016; Morgan, Ryu, \& Mirvis, 2009; Spitzeck, 2009). There is an evidence of sustainability governance structures moving through the developmental stages in the companies. For instance, Spitzeck (2009) found the leadership role of CEO, and increasing use of corporate responsibility committees (almost 60\%) to support the board, in dealing with the corporate sustainability agenda. Similarly, Morgan, et al., (2009) surveyed a representative sample of Fortune 500 Companies and benchmarked how companies are embedding citizenship into their governance, structure, and systems. They found the presence of an enterprise code of conduct and third-party assurance in nearly all the firms. In a recent study, Klettner, et al., (2014) surveyed various governance structures in 50 large Australian companies. Their surveys confirm that almost $60 \%$ of the companies had a board committee dedicated to sustainability, used GRI guidelines for sustainability reporting and explains the methods for stakeholder engagement. $90 \%$ of the companies included nonfinancial performance indicators of the companies' remuneration schemes, signed some sort of sustainability networks and identified their stakeholders. In their study of most sustainable companies Lock \& Seele (2016) found that 92.7\%

\footnotetext{
${ }^{2}$ https://www.bsr.org/en/our-insights/blog-view/how-to-build-effective-sustainability-governance-structures
} 
of the most sustainable companies has in place governance structures for CSR.

The study also indicated that $80.5 \%$ of the examined firms have also installed a governance board or committee that will be solely responsible for CSR. Findings also confirmed that at the operational level, CSR is organized mostly in stand- alone departments. Overall, the studies mentioned above confirm that companies are increasingly incorporating sustainability governance practices in their organisations.

There are recent demands for recognition of sustainability issues up to the boardroom and the C-suite executive level (Global Reporting Initiative, 2013). Number of companies that started to realize the important role a board must play are increasing (UNGC, 2012). As a result, firms are embedding sustainability concerns in their corporate governance practices for better management and monitoring (IFAC 2012). The Governance of Sustainability starts from the top management of the company. Board of directors play an important role in driving the sustainability agenda and initiating the sustainable corporate strategies. Board's commitment to sustainability is also essential as they must set corporate goals and strategies in accordance with the need for balancing the interests of key stakeholders (Salvioni, Gennari, \& Bosetti, 2016). To embed the sustainability principles into goals and behaviors, there must be a strong leader who knows the way, goes the way and shows the way to his followers. Sustainability oriented board acts as a change agent and alters the decision making variables in the favor of sustainable business practices (Mostovicz, Kakabadse, \& Kakabadse, 2009; Salvioni, et al., 2016). Establishment of devoted social and environmental-related committees at board level is an expression of board's commitment to sustainability. The presence of a separate CSR committee leads to more engagement in sustainability actions and better sustainability performance (Eccles, Ioannou, \& Serafeim, 2014).

Another governance mechanism initiated by firms is the appointment of executive officer position responsible for sustainability issues. Chief Sustainability Officer (CSO) is the most relevant executive position relating to sustainability (Salvioni, et al., 2016). The literature showed that approaches to sustainability differs between companies depending on who are involved in sustainability decisions (Doppelt, 2017). The CSO represents an influential figure inside the firm in relation to sustainability initiatives and commitments. The CSO is generally responsible for the promotion of sustainability considerations throughout the organization, executive suite, and Board of Directors. Their appointment is justified on the ground of their practice and specific role in integrating strategies, governance practices and activities within the executive position and organization.

Appointment of CSO represents the top management commitment aimed at satisfying the broad range of sustainability issues. Empirical studies documented a positive relationship between the existence of CSO and sustainability disclosure, however quality of such disclosures remained undiscovered (Peters \& Romi, 2014). Executive remuneration is another variable that is related to the governance of sustainability. By linking executive remuneration to the long-term performance and non-financial targets, the focus can be shifted from profit maximization only to sustainable development. Sustainability related executive remuneration encourages the balance of short-term and long-term as well as financial and socio-environmental objectives for stakeholder (Mostovicz, et al., 2009; Salvioni, et al., 2016; Schaefer, 2004).

Theoretically, legitimacy theory, stakeholders' theory and resource dependence theory explain the need for sustainability governance systems (Wang \& Sarkis, 2017). From the perspective of legitimacy theory, through sustainability governance organizations seek legitimacy of internal and external agents for socially beneficial outcomes. Theoretically effective sustainability governance structures ensures sustainability performance in the future (Schneider \& Meins, 2012). However, empirical evidence is mixed on the role of board-level participation on sustainability management and reporting. For instance, Rodrigue, Magnan, \& Cho (2013) explains the passive role of the board and no association between sustainability committees and sustainability performance. On the other hand, some researchers (e.g. Peters \& Romi, 2014) correlated the present of committee and CSO positively with the likelihood of sustainability disclosure. Mahmood, Kouser, Ali, Ahmad, \& Salman (2018) also found positive association between presence of CSR committee with sustainability disclosure and performance. From the perspective of stakeholders' theory, sustainability governance system is needed to satisfy the needs of broad range of stakeholder and for stakeholder accountability rather than stakeholder management. Effective sustainability governance enables the implementation of sustainability strategy 
and reporting process in the organization, hence ensuring overall accountability ${ }^{3}$ to stakeholders. From the perspective of resource dependence theory, sustainability governance can be a source of competitive advantages for a firm (Porter \& Van der Linde, 1995).

Although number of studies that document the sustainability structures exists, extant literature is limited in the adoption and implementation of sustainability governance in emerging and developing economies. There is not even a single study in the context of sustainability governance in the middle east. According to IFC (2010) listed companies in the middle east have achieved substantial improvements in corporate governance and disclosure. Investor demand for sustainability disclosures is limited in the middle east, yet there is growing awareness among companies that sustainability disclosure as the next level of transparency required. Despite the facts of the initiation of the securities markets to number of significant governance reforms and the establishment of new requirements in the MENA countries, however the component of ESG is still needs to be extended to include the environmental and social aspects. The research report by IFC (2010) also suggests that country level ESG performance is lagging.

Sustainability understanding and action at government levels currently is fragmentary. On the national strategic plans level, although it can be noticed the incorporation of sustainable developments aspect, however the measurements of the countries ESG performance reflects that it is still at its earliest stages of being put into practice. The issue of the implementation gap in each of the environmental, social and governance policy are obvious at the national and corporate level. Addressing such implementation gaps will be important to bolster sustainability credentials in the middle east. Therefore, this research aims to explore how the governance structure and process are being reported in the top 50 middle eastern companies' sustainability reports.

\section{Methods for Data Collection and Analysis}

A form of content analysis is used in this study, whereby the annual and CSR/sustainability reports were reviewed against pre-defined sustainability governance variables. Krippendorff, 2013 (p.24) considers content analysis as " $a$ research technique for making replicable and valid inferences from texts (or other meaningful matter) to the contexts of their use". Despite of some methodological issues, content analysis is a well-established technique in social and environmental reporting research (Unerman, 2000; Vourvachis \& Woodward, 2015) Most of existing studies in sustainability governance mentioned above have also used this type of methodology. The decision to select the coding categories is most important part of designing a process of content analysis. The categories (Appendix A) were selected in the light of existing studies, documents on best practices of sustainability governance and GRI guidelines of sustainability reporting and governance. Our work builds on and supports existing studies. As with Schneider \& Meins (2012) this study used two levels: Structural and Procedural. This study merged the two procedural levels into one. In this study, content analysis is used as a method of measuring the presence or absence of governance structures which will enable us to derive patterns. In addition to this, qualitative content analysis is performed which enable us to capture how companies are incorporating sustainability governance structures and processes in the middle east.

Sample companies in this research were taken from the S\&P/Hawkamah Pan Arab ESG Index that include the top 50 MENA companies listed on the national stock exchanges of 11 markets of MENA countries including: Kingdom of Saudi Arabia, the United Arab Emirates, Kuwait, Bahrain, Qatar, Lebanon, Oman, Egypt, Tunisia, Morocco and Jordan. The index includes companies based on their performance on about 200 ESG metrics, when compared to their regional peers. Top ten constituents of the index from the year 2016 to 2018 were chosen which resulted in a sample of 15 companies. Sustainability / CSR reports were then collected for those 15 companies. Details of sample companies provided in Table 1 below. The S\&P/Hawkamah Pan Arab ESG Index as a population was chosen in a pragmatic approach to reflect the current best practices across a variety of middle eastern countries. Companies that are listed on the index are those that are publishing their sustainability information in line with various sustainability related guidelines and they can be considers as leaders in embedding and implementing sustainability structures. NVivo (software for qualitative data analysis) was used for coding the instances of various sustainability structures to capture the extent as well as content and context of such structures. The analysis is then presented in the form of percentages,

\footnotetext{
${ }^{3}$ https://www.bsr.org/en/our-insights/blog-view/how-to-build-effective-sustainability-governance-structures
} 
graphs and narratives, providing examples of how sustainability structures are disclosed in the reports.

\begin{tabular}{|c|c|c|c|c|c|}
\hline No & Country & Company & 2018 & 2017 & 2016 \\
\hline 1 & Saudi Arabia & Saudi Basic Industries Corp & First & Fourth & Fifth \\
\hline 2 & U.A.E & First Abu Dhabi Bank & Second & Sixth & First \\
\hline 3 & U.A.E & Abu Dhabi Commercial Bank & Third & Second & Third \\
\hline 4 & Jordan & Arab Bank & Fourth & Fifth & Fourth \\
\hline 5 & U.A.E. & Dana Gas PJSC & Fifth & & \\
\hline 6 & Saudi Arabia & Saudi Investment Bank & Sixth & Seventh & Sixth \\
\hline 7 & Qatar & Qatar National Bank & Seventh & & \\
\hline 8 & Qatar & Vodafone Qatar & Eighth & & \\
\hline 9 & Oman & Bank Muscat International & Ninth & & \\
\hline 10 & Qatar & Agility & Tenth & & \\
\hline 11 & U.A.E & DP World & & First & Second \\
\hline 12 & U.A.E & Aramex Company & & Third & Ninth \\
\hline 13 & Lebanon & Bank Audi & & Eighth & Eighth \\
\hline 14 & Saudi Arabia & Savola Group & & Ninth & Seventh \\
\hline 15 & Kuwait & Mobile Telecommunications Company (Zain) & & Tenth & Tenth \\
\hline
\end{tabular}

\section{The Governance of Corporate Sustainability in the Middle East}

Among the leading structures of sustainability governance in the middle eastern companies that are listed on the index include the presence of code of conduct (100\%), sustainability strategy (93\%) and sustainability policy (86\%). The code of conduct is mainly related to ethical issues and in some instances reflect environmental protection. Islamic values are also reflected by some companies in describing their code of conduct. Following narratives from the sustainability and CSR reports of sample companies illustrate how companies are exhibiting code of conduct related to ethics and sustainability.

"Our commitment to ethics and compliance is fundamental to our ability to create value, support the communities in which we operate, and protect our reputation. Operating with integrity is something we strive to do every day to earn and keep stakeholder trust, and it is one of our most important values". [SABIC Sustainability Report 2017]

"All our relationships and interactions are governed through the four ethics of Honesty (Amanah), Conscientiousness (Taqwa), Caring Justice (Birr), and Personal Control (Mujahadah)" [Savola Group Sustainability Report 2014/2015]

"Health, Safety \& Environmental Protection: Agility's Code requires that offices and workplaces be safe for employees, and that our products and services are not injurious to public health, safety or the environment." [Agility Corporate Social Responsibility Report 2016]

As far as sustainability strategy and policy is concerned, few middle eastern companies are proactively devising strategies and sustainability frameworks in line with the national sustainable development agenda as well as changing global trends as well as societal expectations. Following narratives from the sustainability and CSR reports of sample companies illustrate how companies are exhibiting their sustainability strategies and frameworks. 
"Doing more is the forte of bank muscat - more for the economy, more for the community, and more for the nation. The sustainability and CSR strategy pursued by bank muscat is focused on delivering long-term benefits to the community and the nation." [Bank of Muscat Sustainability Report 2017]

"Our strategy is guided by these global trends as well as changing societal expectations in our key geographies. For example, Saudi Arabia's Vision 2030 offers the country an ambitious blueprint for sustainable growth, and as the largest publicly traded company in Saudi Arabia, we have shaped our say corporate 2025 strategy to enable the success of the country's Vision 2030." [SABIC Sustainability Report 2017]

"SAIB recognizes that banks play an important role in helping societies grow and in developing a sustainable economy. The objective of our sustainability strategy is to influence all stakeholders to adhere to practices that benefit society, the environment, and contribute to sustainable development of Saudi Arabia" [The Saudi Investment Bank Sustainability Report 2016]

"FAB Sustainability Framework Pillars Process Deliver smooth integration Ensure safety for all stakeholders. At the outset of our integration journey, our senior leadership felt it was important to articulate FAB's firm commitment to sustainability, which is part of our long-term corporate direction. As the UAE's largest bank, we have a responsibility as a corporate citizen toward the economy, the environment and society." [First Abu Dhabi Bank Corporate Sustainability Report, 2017].

"As an organization committed to promoting sustainable development, Zain aligns its business activities and the sustainability strategy with the Post-2015 Sustainable Development Agenda." [Zain Sustainability Report 2017]

The management of sustainability involves a designated person for sustainability affairs as well as representation in the board through sustainability committee. Almost 53\% companies have designated head of sustainability. Among the designations that are responsible for managing sustainability in few of sample companies include Director, Corporate Social Responsibility (Agility); Head of Corporate Sustainability (Zain); Head of CSR (Bank Audi); VP \& Head of Corporate Sustainability Message (Savola Group); Head of Corporate Responsibility (Vodafone Qatar); Head - CSR and Sustainability Initiatives (Dana Gas).

"Sustainability issues, including the socio-economic and environmental impacts of Zain, fall under the responsibility of the Head of Corporate Sustainability (CS), who develops the company' sustainability strategy, Sustainability KPIs and coordinates with relevant stakeholders to communicate key issues both internally and externally as deemed necessary. Impacts and other issues pertaining to these themes are reported to both Executive Management and the BOD by the Head of CS through a variety of tools that include periodic reports such as quarterly performance reviews and the annually published Sustainability Report." [Zain Sustainability Report 2017]

\section{SUSTAINABILITY GOVERNANCE - STRUCTURAL}

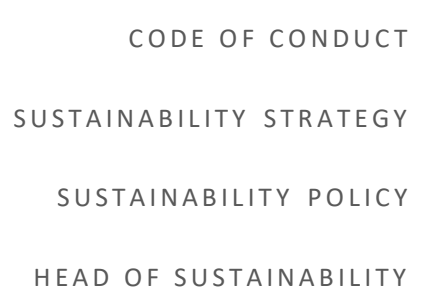

SUSTAINABILITY RELATED MISSION \& VISION

SUSTAINABILITY COMMITTEE

VALUES RELATED TO SUSTAINABILITY

SUSTAINABILITY DEPARTMENT

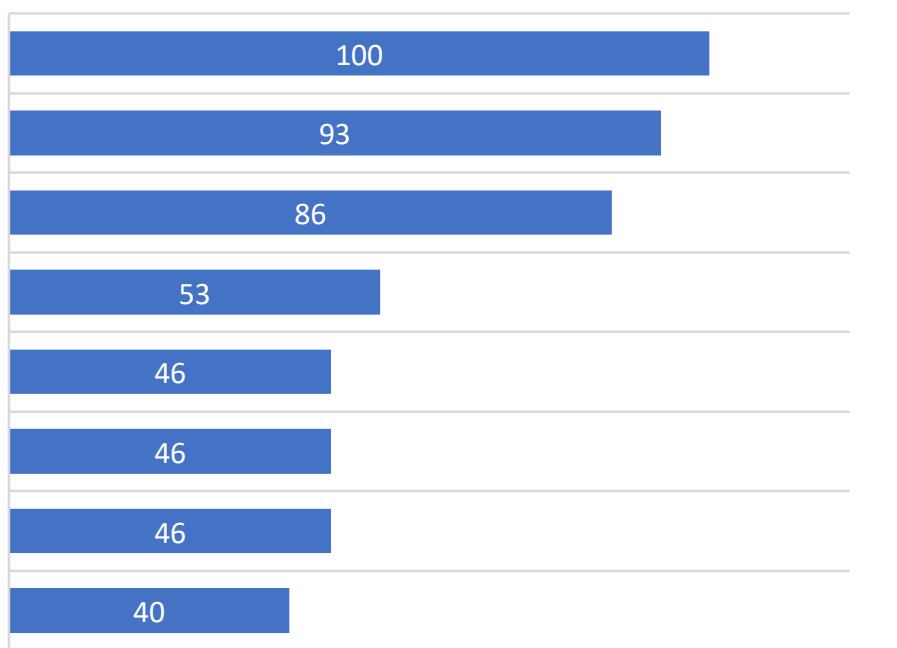


To engage more with corporate sustainability, $46 \%$ of the sample companies have established a devoted social and environmental-related committee at board level. Among the companies that have separate committee for managing sustainability, few companies have just mentioned the presence of the committee in their reports without any other details. However, a small number of companies have well defined and diversified sustainability committee which are comprehensively disclosed in their sustainability reports as exhibited by the following narratives.

"The SAIB Sustainability Committee is the strategic leadership body responsible overseeing, advising, and advocating for the successful implementation the SAIB Sustainability Framework and Policy throughout the organization" [The Saudi Investment Bank Sustainability Report 2016]

"The CSR Committee consists of five members, each with relevant experience and most being nonexecutive. In fulfilling its roles and responsibilities, the Committee held two meetings in 2014 and three meetings during 2015 to review the Group's CSR programs and activate the Group's role in CSR through the adoption of CSR initiatives and programs, setting criteria and developing plans to serve the community." [Savola Group Sustainability Report 2014/2015]

Sustainability governance structures that are least present in the sample companies include the presence of separate sustainability department and sustainability related mission, vision and values. In $40 \%$ of the companies, there is a separate department that is responsible for managing sustainability. The sustainability department in these companies works with other departments through sustainability teams. In some companies, sustainability department falls under Branding department while in other cases it falls under the Corporate Affairs and Corporate Communications department.
"At Arab Bank, sustainability is an integral part of our day to day operations, through clear management lines. In 2011, the Bank established the Sustainability Department, which coordinates all the sustainability efforts across the Bank with other departments through the Sustainability Champions. The Sustainability Department falls under the Branding Division, which reports directly to the Chief Executive Officer (CEO) on all progress on sustainability programs and initiatives." [ARAB Bank Sustainability Report 2017]
"Our Corporate Sustainability department reports directly to our Corporate Affairs function - a structure that accelerates the pace of change by facilitating communication of progress and enabling closer relationships with external stakeholders. Making our sustainability communications frequent and clear helps us to inspire employees and embed sustainability into the company culture." [SABIC Sustainability Report 2017]

Almost $46 \%$ of the companies are embedding sustainability into their mission, vision and values. Upon closer examination of the corporate values, it was observed that very few companies have referred sustainability specifically into their corporate values. One example where corporate values directly refer to sustainability is as follows.

"We aim to provide a safe and environmentally friendly workplace for our employees and business partners, and to minimize the adverse effects of our operations on communities and the environment." [Our Value: Dana Gas Sustainability Report 2017]

Sustainability seems to be missing element in the mission and vision of most of the companies. Among companies that refers to sustainability in their mission and vision, sustainability refers mainly to sustainable value creation for stakeholders. Following narratives from the sustainability and CSR reports of sample companies illustrate how companies are referring to sustainability in their mission and vision.

"To be the leading private sector natural gas company in the Middle East, North Africa and South Asia (MENASA) region generating sustainable value for our stakeholders." [Dana Gas Sustainability Report 2017]

"Creating value for our customers, employees, shareholders and communities to grow stronger through differentiation, agility and innovation." [First Abu Dhabi Bank Sustainability Report 2017] 
"At Savola, we exist to empower, inspire and strategically guide our companies, partners, customers and employees through supportive programmes and core values.... We add value for investors, employees and wider society. We are a business run for people, by people. This is why Savola's mission is to have a positive impact on society, while generating profits and growth through strategic investment in the MENAT (Middle East, North Africa and Turkey) region..." [Savola Group Sustainability Report 2014/2015]

In some cases, companies have devised separate mission and vision related to sustainability as follows.

"To achieve its sustainability objectives, Arab Bank established a sustainability vision of becoming the leading responsible financial institution in the Arab world socially, economically and environmentally. This vision is backed by a sustainability mission that aims to create long-term sustainable financial and non-financial value for the Bank and its stakeholders through continuous support and contribution to the achievement of their ambitions. Embracing this vision and mission as a foundational guide to the Bank's sustainability management will enable Arab Bank to deliver on its sustainability objectives and realize the opportunity in implementing the sustainability strategy." [ARAB Bank Sustainability Report 2017]

Committed leadership is necessary for the promotion and integration of sustainability considerations throughout the organization. The analysis confirmed the presence of committed leadership in all the sample companies as evident from the following statements by the leaders of their respective organisations.

"We are committed to creating a positive social footprint in the communities we serve" [Qatar National Bank Sustainability Report 2017]

"ADCB is committed to addressing issues that directly and indirectly impact our business—and our stakeholders' decisions to do business with us. Corporate responsibility and sustainability are becoming increasingly important issues, and we actively support the development of a more sustainable business environment and society at large. We believe our integrated approach will build maximum long-term value for our customers, shareholders, employees, communities and country." [Abu Dhabi Commercial Bank Sustainability Report 2017]

".... I would like to emphasize our ongoing commitment to be aligned with the evolving expectations of our stakeholders, aiming to meet their goals and ambitions and to drive positive economic, social and environmental change to our communities, today and in the future." [ARAB Bank Sustainability Report 2017]

"As the leading financial institution in the Sultanate, bank Muscat continues to deliver on its commitment to the people and the nation through strategic corporate social responsibility (CSR) programmes covering various segments, such as youth, sports, education, and SMEs. Sustainability is a running theme in all stakeholder engagement initiatives and activities, ensuring lasting positive benefits aimed at strengthening ties with the local community." [Bank of Muscat Sustainability Report 2017]

"We are committed to our sustainability roadmap for 2020, as we believe that it will enhance value for the Company and create benefits for all our stakeholders." [Dan Gas Sustainability Report 2017]

"Our sustainability agenda at FAB supports our long-term ambition to be a leading bank and a strong business partner on issues that have global significance and local relevance." [First Abu Dhabi Bank Sustainability Report 2017]

"Sustainable business practices are becoming increasingly important for the Kingdom as it strives to foster a thriving business environment, vibrant community, and globally competitive economy.... Our efforts in these areas stem from our growing commitment to corporate sustainability.... The Saudi Investment Bank will continue to accelerate the Kingdom toward its vision of sustainable success for years to come. We are investing in the Kingdom of tomorrow" [The Saudi Investment Bank Sustainability Report 2016]

"... we are dedicated to achieving our economic, environmental and social goals. We cannot envisage long-term success without an equal and parallel commitment to each of these three aspects. Our deepest gratitude goes towards all stakeholders that support us and hold us accountable for achieving our sustainable business goals. We look forward to delivering on your expectations." [Vodafone Qatar Sustainability Report 2015-2016] 


\section{SUSTAINABILITY GOVERNANCE - PROCEDURAL}

COMMITMENT FROM LEADERSHIP

STAKEHOLDER ENGAGEMENT

ENVIRONMENTAL MANAGEMENT SYSTEM

SUSTAINABILITY GUIDELINES

SUSTAINABILITY TEAMS

UNGC MEMERSHIP

SUSTAINABILITY RELATED TRAINING

SUSTAINABILITY ASSURANCE

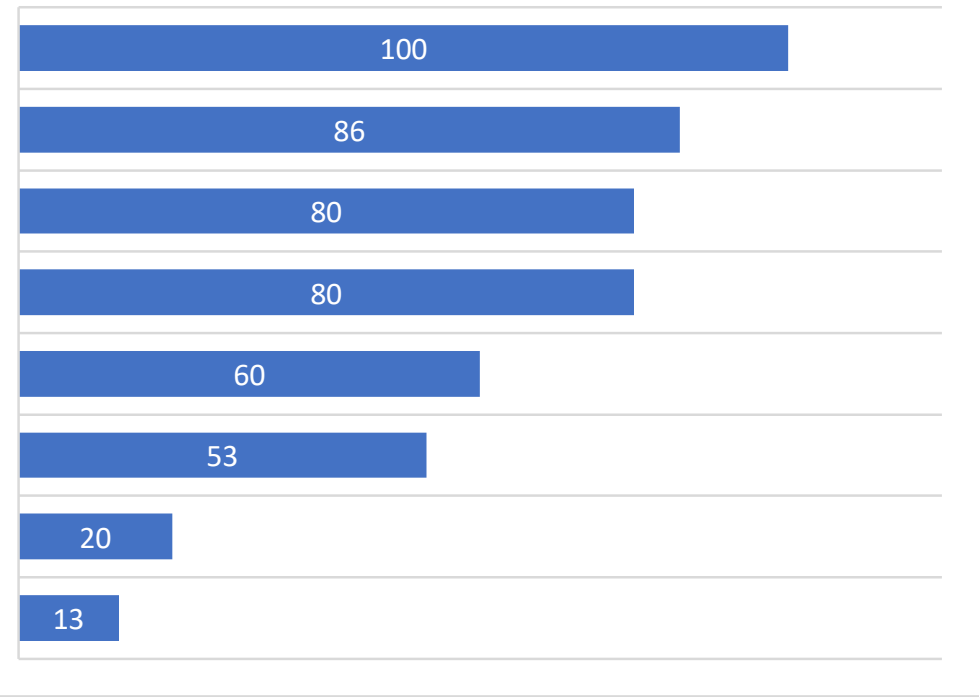

Stakeholder engagement is an important mechanism for ensuring corporate sustainability. Almost $90 \%$ of the companies describe their process of engagement with stakeholders and mentions wide range of stakeholders in their sustainability report. Few companies also highlight the importance of stakeholder engagement as a procedural mechanism to decide priority areas and to ensure sustainable value for all stakeholders. Following narratives from the sustainability and CSR reports of sample companies illustrate how companies are referring to stakeholder engagement as an important mechanism of sustainability governance.

"Engagement with our stakeholders helps us to shape our CSR priorities and program execution, as well as our CSR reporting. [Agility Corporate Social Responsibility Report 2016]

"Arab Bank sustainability approach is based on comprehensive engagement with our stakeholders to enable us to identify their needs and expectations, and align them with our business case for sustainability, thereby shaping an approach that ensures value for all stakeholders. [ARAB Bank Sustainability Report 2017]

"Recognizing the value of each stakeholder, Bank Audi made sure to continuously engage its external and internal stakeholders, to seek their critical input, and to monitor their expectations. Therefore, and similar to previous years, it held a special stakeholders' panel reflecting its corporate values and aimed at inviting stakeholders to discuss the Bank's strategy and initiatives, and to identify important gaps and directions for the future. [Bank Audi Sustainability Report 2017]

Eight percent of the sample companies are implementing and continuously updating social environmental management system. These systems improve the monitoring and implementation of sustainability performance within organisations through better information and results. Similar percentage $(80 \%)$ of the sample companies are using GRI (Global Reporting Initiatives) guidelines for reporting on sustainability. Both mechanisms can be considered as procedural level mechanisms of sustainability governance as they enable companies to better monitor and control their sustainability activities. Both EMS and Sustainability reporting improves the information system and transparency for business improvements. Following narratives from the sustainability and CSR reports of sample companies illustrate how companies are incorporating EMS and GRI as part of sustainability governance.

The bank continually endeavors to ensure effective social and environmental management practices in all its activities, products, and services, with a special focus on ensuring that all activities undertaken by the bank are consistent with the Board approved SEMS policy. The SEMS policy was adopted by the bank in addition to the procedure to comply with the Equator Principles. We have also implemented social and environmental management procedures for providing loans to customers." [Bank of Muscat Sustainability Report 2017]

"..Our EMS in the UAE and Egypt are in line with the ISO 14001 requirements and include environmental performance plans, 
procedures and documentation controls" [Dana Gas Sustainability Report 2017]

"..... the Bank maintained its commitment to manage Environmental and Social (E\&S) risks in its Corporate and Commercial Banking activities by enhancing its Environmental \& Social Management System (ESMS)." [Bank Audi CSR Report 2017]

"Arab Bank has also been reporting on sustainability using the Global Reporting Initiative (GRI) guidelines since 2010; the most recognized and widely used guidelines for sustainability reporting globally. Over the past seven years, the Bank has been expanding the scope of disclosure and transparency in each sustainability report, to align with our sustainability strategic objectives." [ARAB Bank Sustainability Report 2017]

$60 \%$ of the sample companies have sustainability Teams and $53 \%$ of the sample companies are members of UNGC and incorporate UNGC 10 principles for embedding sustainability into their business practices.

"Dana Gas has a dedicated team with representatives from various departments (HSSE, CSR, Investor and Government Affairs and Country Representatives) to engage with DG's stakeholders, and to monitor the company's sustainability performance." [Dana Gas Sustainability Report 2017]

"The Corporate Sustainability (CS) team manages FAB's corporate sustainability activity. The team, which is part of the bank's Group Marketing and Communication department, is responsible for developing the Group Corporate Sustainability Strategy and driving FAB's sustainability agenda forward and managing the bank's community and outreach programmes and the internal tactical sustainability awareness programmes. The team also tracks performance and reports on progress through collaboration with the Group's businesses and serves as a strategic sustainability advisor to ensure that the bank meets its sustainability objectives and commitments." [First Abu Dhabi Bank Sustainability Report 2017]

"In addition, the Sustainability Champions program was created as an internal tool to support the effective integration and implementation of the sustainability strategy across the Bank's departments. Sustainability Champions are employees from different divisions including: Procurement, Risk Management, Corporate and Institutional Banking, Consumer Banking, Human Resources, Real Estate and Construction Management, Compliance, Operations and Internal Audit. Working closely with the Sustainability Department, the team of Champions contributes to shaping and implementing the sustainability strategy within their divisions, ensuring that all sustainability objectives, initiatives, and targets are handled in their respective departments. They are also involved in the preparation of the Bank's annual Sustainability Report." [ARAB Bank Sustainability Report 2017]

"Zain conducts regular materiality assessments through its operations reviews, monthly engagement with the operating companies' sustainability teams and management meetings to define the themes that are most material to the organization and its key stakeholders." [Zain Sustainability Report 2017]

"Our sustainability strategic objectives ensure that our business activities add value not only to the bottom-line, but also to people, communities and the planet. Thus, our comprehensive sustainability strategy is aligned with a number of global standards that support our national development agenda, including the UN Global Compact (UNGC) principles and the Sustainable Development Goals (SDGs). Additionally, our strategy and management of sustainability issues are aligned with ISO 26000 Social Responsibility Standards." [ARAB Bank Sustainability Report 2017]

The least followed mechanism for embedding sustainability is the training related to sustainability (20\%) and thirdparty assurance of sustainability reporting (13\%). Both these mechanisms are important as they ensure the future potential of an organization in achieving corporate sustainability. Although organisations mentions lot of trainings but sustainability related are very less.

"Agility's ethics training program is designed to provide employees with access to courses appropriate to their work. Training in ethics and compliance is delivered online and in classroom sessions. Since 2007, we have enrolled more than 39,000 people into our online ethics training courses. The majority are employees, but we also extend training to some key suppliers or contractors. Most of these enrollees are required to complete more than one online ethics course. Agility's ethics courses teach our employees how to deal with real world situations. Topics include anti-trust, anti-corruption, conflicts of interest, competition law, environmental protection, health and safety, human rights, intellectual property, and government 
procurement." [Agility Corporate Social Responsibility Report 2016]

"Delivered sustainability awareness training to staff through internal and external seminars, educational tours and intranet communications" [Our Achievements, Abu Dhabi Commercial Bank Sustainability Report 2017]

There is no assurance of sustainability reports in middle east which means that not only the credibility of these statements is at stake but also the improvement opportunities that may result from the assurance process is also missing. However, some organisations understand the importance of and possible demands for sustainability assurance in the future. These organisations are considering adopting sustainability assurance in future. Only in two cases (SABIC and Zain) sustainability assurance is practiced and disclosed.

"This report has not been assured by a third party." [ARAB Bank Sustainability Report 2017]

"This report has not been externally assured. However, we may seek for external assurance in the future." [Dana Gas Sustainability Report 2017]

"This report did not undergo external assurance." [The Saudi Investment Bank Sustainability Report 2016]

"We have opted out of independent assurance for nonfinancial disclosures, although we may take these steps into consideration for future reports." [Vodafone Qatar Sustainability Report 2015-2016]

"We believe external assessments improve our sustainability reporting, and for the last six years we have used KPMG to increase our confidence in certain reported data. The limited assurance engagement includes absolute and intensity operational metrics: energy consumption, greenhouse-gas emissions, freshwater usage, material loss, flaring reduction and $\mathrm{CO} \cdot$ utilization, as well as selected corporate environment, health, safety, and security metrics, and compliance, as noted in the KPMG assurance report and marked by "*" throughout the report. For compliance data, we have applied a more limited scope." [SABIC Sustainability Report 2017]

\section{Discussion and Conclusion}

The results presented into this paper shed the light on some of the structures and processes being employed by 15 middle eastern companies (listed in the S\&P/Hawkamah Pan Arab ESG Index) to govern and manage their sustainability strategies. The results of this study showed that sustainability is getting infused and embedded in governance structures and processes of the company. This research found that sample companies are catching up the global best practices in incorporating sustainability into some of their structures and processes. For example, 100\% sample companies have committed leadership and code of conduct related to sustainability. More than $80 \%$ of the sample companies have sustainability strategy and framework, Environmental Management System, following GRI guidelines for preparing sustainability reports and engages with wide range of stakeholders in a systematic manner. More than 50\% of the companies have dedicated head of sustainability, sustainability teams and membership of UNGC. These findings resonate with the existing studies, mostly in developed countries (Klettner, et al., 2014; Lock \& Seele, 2016; Morgan, et al., 2009; Spitzeck, 2009). However, sustainability governance structures where sample companies are lagging (in comparison to existing studies cited above) include sustainability committee at board level (46\%), sustainability related mission and vision (46\%), values (46\%), separate sustainability department (40\%) sustainability related trainings (20\%) and sustainability assurance (13\%). Existing studies cited above confirms the presence of sustainability committee at board level in at least $60 \%$ of the companies studied. Similarly, Klettner et al., (2014) found 100\% of 50 large Australian firms employ third part assurance while in case of middle east only $13 \%$ employ third part assurance.

The governance of sustainability requires strategic management, commitment, leadership, monitoring, implementation and communications (Benn, et al., 2014; Klettner, et al., 2014). These can be considered as structural and procedural elements of sustainability governance (Schneider \& Meins, 2012). The sustainability and CSR reports reviewed in this research suggest that sample companies are progressing towards integrating sustainability into both structural and procedural elements of sustainability governance. Results indicates that sustainability debate has found its way into governance structures. Sustainability is now not only on the agenda of CEO but also other board members. Some corporate boards are making more use of a dedicated CR committee. Next to the CEO and board members, head of 
sustainability is become the lead role for sustainability issues (Salvioni, et al., 2016). Companies are increasingly using environmental management system for monitoring and global reporting initiative sustainability reporting guidelines for communication. Overall, large Middle Eastern companies are willing to engage and communicate the results of sustainability strategies to interested stakeholders. However, one area where sample companies are making compromise is the independent assurance of sustainability reporting which is necessary not only for the credibility of sustainability reports but also the review and improvements of existing sustainability structures and initiatives. Although companies are realizing the important of assurance and have plans for implementing it in the future, only two companies so far are providing third-party assurance of sustainability information disclosed in sustainability reports.

While analyzing the narratives of companies to describe sustainability structures and process, there appears to be a consensus that efforts towards improved corporate sustainability are value added to the organisation. There is also a consensus that sustainability governance, by providing necessary structures and processes, paves the way for achieving sustainability even in tough business environments (Schneider \& Meins, 2012). That is why sustainability is becoming more and more integrated into business strategy and more and more companies are integrating sustainability into existing corporate governance systems (Asif, et al., 2011; Asif, et al., 2013). From this, one can infer a sort of business case of sustainability governance that considers the demands of both shareholders and stakeholders both as an opportunity and a possible solution in very market constrained circumstances (Salvioni, et al., 2016). It could also be suggested that this is an evidence of shift at the national level and corporate attempt to work for national sustainable development agenda. As highlighted in the introduction of this paper, some of the middle eastern countries intends to become sustainable and has included sustainable development as one of the key goals of the vision. It was observed in our study that companies are crafting their mission and vision to reflect their alignment with the national agenda.

The information presented in this paper can be used by policy makers and practitioners to better understand the current practices and to make decisions about their policies and actions. Policy makers may decide about the possible regulation required in sustainability governance and practitioners may decide whether and how to adopt and disclosure sustainability governance structures and processes. In our opinion, this research is felicitous, demonstrating not only the areas where middles eastern companies are advancing but also revealing the areas where they are lagging. Most of the middle eastern countries and striving to be sustainable and are incorporating sustainable development into some national strategic plans. However, as confirmed by IFC (2010) country level ESG performance is lagging. This may be because of the implementation gaps in environmental, social and governance policy that may prevail at the national as well as corporate level. Addressing such implementation gaps will be important to bolster sustainability credentials in the middle east. These facts, observations and findings leads to make two suggestions. First companies must learn from the practice of leaders and must take extra steps to embed sustainability into their business practices. Through this research, companies are encouraged to pursue the upward trend towards corporate sustainability through improvement of sustainability governance structures and processes.

Second, there is a need of some government intervention in the form of regulatory guidance on sustainability governance practice and reporting. This regulation could be achieved through securities and exchange commission or stock exchanges and/or through amendments in the corporate governance principles. The regulation may include best practices in sustainability governance as mentioned in the Global Reporting Initiative (GRI) guidelines.

The regulation shall be intended to help Middle eastern companies to clearly grasp how they can combine and integrate sustainability governance within their existing corporate governance systems and to enhance, improve and advance their communications channels to reflects their exerted efforts to the interested stakeholders (Klettner, et al., 2014). This research contributed to the literature on corporate governance and sustainability by providing evidence that companies needed to take in their accounts not only the interests of shareholders but also that of stakeholders. It also contributes to the literature on sustainability governance especially in the context of middle eastern companies in terms of how and to what extent companies are using structures and processes related to sustainability governance. Overall, this paper posits that companies which takes stakeholders interests into account when developing their firm strategies will enable them to move toward better corporate sustainability monitoring, practices, and reporting. 
This research is not without limitations. Sample size is small (15 companies) and represents companies listed in the S\&P/Hawkamah Pan Arab ESG Index. Future research may include more companies from different stock exchanges in the middle east for better generalization. Future research may also focus on other emerging economies. Presence of sustainability structures does not mean that companies are integrating sustainability with their business practices. Future research may include in-depth case-studies to reveal whether companies are truly embedding sustainability within their core business strategy. Future research may also gauge the impact of sustainability governance on social and environmental performance. A business case of sustainability governance may be established through empirical investigation of sustainability governance on business performance. This paper call for further research in the area sustainability governance which falls at the intersection of corporate governance and sustainability. 


\section{References}

Academy, S. (2017). Gulf Region Sustainability and CSR Trends in 2017 Retrieved 01/10/2018, from https://sustainabilityacademy.org/gulf-region-sustainability-csr-trends-2017/

Aras, G., \& Crowther, D. (2008). Governance and sustainability: An investigation into the relationship between corporate governance and corporate sustainability. Management Decision, 46(3), 433-448.

Asif, M., Searcy, C., Zutshi, A., \& Ahmad, N. (2011). An integrated management systems approach to corporate sustainability. European Business Review, 23(4), 353-367.

Asif, M., Searcy, C., Zutshi, A., \& Fisscher, O. A. (2013). An integrated management systems approach to corporate social responsibility. Journal of cleaner production, 56, 7-17.

Benn, S., Edwards, M., \& Williams, T. (2014). Organizational change for corporate sustainability: Routledge.

Boiral, O. (2007). Corporate greening through ISO 14001: a rational myth? Organization Science, 18(1), 127-146.

Cadbury, S. A. (2000). The corporate governance agenda. Corporate Governance: An International Review, 8(1), 7-15.

Chartered, S. (2018). Asia Sustainable Investing Review

De Graaf, F. J., \& Stoelhorst, J. (2013). The role of governance in corporate social responsibility: Lessons from Dutch finance. Business \& Society, 52(2), 282-317.

Doppelt, B. (2017). Leading change toward sustainability: A change-management guide for business, government and civil society: Routledge.

Eccles, R. G., Ioannou, I., \& Serafeim, G. (2014). The impact of corporate sustainability on organizational processes and performance. Management Science, 60(11), 2835-2857.

Gray, R., Adams, C., \& Owen, D. (2014). Accountability, social responsibility and sustainability: accounting for society and the environment: Pearson Higher Ed.

IFC. (2010). Sustainable Investment in the Middle East and North Africa International Finance Corporation.

Issa, N. S. C., \& Al Abbar, S. D. (2015). Sustainability in the Middle East: achievements and challenges. International Journal of Sustainable Building Technology and Urban Development, 6(1), 34-38.

Klettner, A., Clarke, T., \& Boersma, M. (2014). The governance of corporate sustainability: Empirical insights into the development, leadership and implementation of responsible business strategy. Journal of Business Ethics, 122(1), 145165 .

KPMG. (2017). The road ahead growing momentum in the corproate responsibility reporting in the UAE.

Krippendorff, K. (2013). Content analysis: An introduction to its methodology (3rd ed.): Sage Publications.

Lock, I., \& Seele, P. (2016). CSR governance and departmental organization: A typology of best Practices. Corporate Governance: The International Journal of Business in Society, 16(1), 211-230.

Mahmood, Z., Kouser, R., Ali, W., Ahmad, Z., \& Salman, T. (2018). Does Corporate Governance Affect Sustainability Disclosure? A Mixed Methods Study. Sustainability, 10(1), 207.

Morgan, G., Ryu, K., \& Mirvis, P. (2009). Leading corporate citizenship: governance, structure, systems. Corporate Governance: The International Journal of Business in Society, 9(1), 39-49.

Mostovicz, I., Kakabadse, N., \& Kakabadse, A. (2009). CSR: the role of leadership in driving ethical outcomes. Corporate Governance: The International Journal of Business in Society, 9(4), 448-460.

Peters, G. F., \& Romi, A. M. (2014). The association between sustainability governance characteristics and the assurance of corporate sustainability reports. Auditing: A Journal of Practice \& Theory, 34(1), 163-198.

Porter, M., \& Van der Linde, C. (1995). Green and competitive: ending the stalemate. The Dynamics of the eco-efficient economy: environmental regulation and competitive advantage, 33.

Rodrigue, M., Magnan, M., \& Cho, C. H. (2013). Is environmental governance substantive or symbolic? An empirical investigation. Journal of Business Ethics, 114(1), 107-129.

Salvioni, D. M., Gennari, F., \& Bosetti, L. (2016). Sustainability and convergence: the future of corporate governance systems? Sustainability, 8(11), 1203.

Schaefer, A. (2004). Corporate sustainability-integrating environmental and social concerns? Corporate Social Responsibility and Environmental Management, 11(4), 179-187.

Schneider, A., \& Meins, E. (2012). Two dimensions of corporate sustainability assessment: Towards a comprehensive framework. Business Strategy and the Environment, 21(4), 211-222.

Spitzeck, H. (2009). The development of governance structures for corporate responsibility. Corporate Governance: The International Journal of Business in Society, 9(4), 495-505.

Spitzeck, H., \& Hansen, E. G. (2010). Stakeholder governance: how stakeholders influence corporate decision making. Corporate Governance: The International Journal of Business in Society, 10(4), 378-391.

Unerman, J. (2000). Methodological issues-Reflections on quantification in corporate social reporting content analysis. Accounting, Auditing \& Accountability Journal, 13(5), 667-681.

Unerman, J., Bebbington, J., \& O’Dwyer, B. (2010). Introduction to sustainability accounting and accountability Sustainability accounting and accountability (pp. 20-35): Routledge. 
UNGC. (2012). A new agenda for the board of directors: Adoption and Oversight of Corporate Sustainability.

Vinke, J., \& El-Khatib, A. (2012). The Development of CSR Reporting in the Middle East. In D. Jamali \& Y. Sidani (Eds.), CSR in the Middle East: Fresh Perspectives (pp. 136-157). London: Palgrave Macmillan UK.

Vourvachis, P., \& Woodward, T. (2015). Content analysis in social and environmental reporting research: trends and challenges. Journal of Applied Accounting Research, 16(2), 166-195.

Wang, Z., \& Sarkis, J. (2017). Corporate social responsibility governance, outcomes, and financial performance. Journal of cleaner production, 162, 1607-1616. 


\section{Appendix A: Coding Categories: Sustainability Governance}

\begin{tabular}{|c|c|c|c|}
\hline \multirow{8}{*}{$\underset{a}{a}$} & 1 & $\begin{array}{l}\text { Dedicated Head of } \\
\text { Sustainability }\end{array}$ & Is there any dedicated head of sustainability hired by the company \\
\hline & 2 & Sustainability Committees & $\begin{array}{l}\text { Is there any formal board committee that is concerned with } \\
\text { sustainability? }\end{array}$ \\
\hline & 3 & Sustainability Department & $\begin{array}{l}\text { Is there any standalone department in a company that is responsible } \\
\text { for sustainability? }\end{array}$ \\
\hline & 4 & Mission and Vision & $\begin{array}{l}\text { Does Mission and Vision Statement of a company refer to } \\
\text { Sustainability issues OR company disclose sustainability related } \\
\text { mission and vision. }\end{array}$ \\
\hline & 5 & Norms \& Values & Does corporate values for corporate sustainability? \\
\hline & 6 & Sustainability Strategy & Does company disclose its sustainability strategy? \\
\hline & 7 & Sustainability Policy & $\begin{array}{l}\text { Does the company have a policy to integrate ESG issues into its } \\
\text { strategy and day-to-day decision making? }\end{array}$ \\
\hline & 8 & Code of Conduct & $\begin{array}{l}\text { Does company have a code of conduct that refers to sustainability } \\
\text { issues. }\end{array}$ \\
\hline \multirow{8}{*}{ 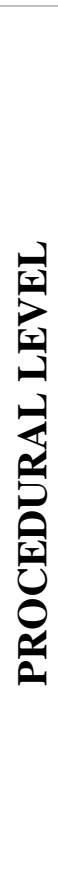 } & 9 & Leadership & $\begin{array}{l}\text { Has there been a statement from a senior management or board } \\
\text { member to clearly articulate company's commitment to integrate } \\
\text { sustainability issues into the day-to-day decision making? }\end{array}$ \\
\hline & 10 & Guidelines & $\begin{array}{l}\text { Does company use any national or international guidelines for } \\
\text { preparing sustainability report? }\end{array}$ \\
\hline & 11 & Assurance & $\begin{array}{l}\text { Does company get their sustainability information assured from } \\
\text { third party? }\end{array}$ \\
\hline & 12 & $\begin{array}{l}\text { Environmental Management } \\
\text { System }\end{array}$ & Is there any environmental management system in place? \\
\hline & 13 & Global Compact & $\begin{array}{l}\text { Is company the signatory of United Nations Global Compact or any } \\
\text { other sustainability network. }\end{array}$ \\
\hline & 14 & Training & $\begin{array}{l}\text { Does company provide sustainability-related training to its } \\
\text { employees? }\end{array}$ \\
\hline & 15 & Teams & $\begin{array}{l}\text { Are there any sustainability teams, working groups and external } \\
\text { advisory councils? }\end{array}$ \\
\hline & 16 & Stakeholder Engagement & $\begin{array}{l}\text { Does company consult and explain the process of stakeholder } \\
\text { engagement? }\end{array}$ \\
\hline
\end{tabular}

